\title{
Determination of management and topographic influences on the balance between resident and 'Grasslands Huia' white clover (Trifolium repens) in an upland pasture using isozyme analysis
}

\author{
A. HOPKINS ${ }^{2}$, M. G. LAMBERT ${ }^{1}$, D. J. BARKER ${ }^{1 *}$, D. A. COSTALL ${ }^{1}$, P. M. SANDERS ${ }^{1}$, \\ A. G. SCOTT ${ }^{1}$ AND W. M. WILLIAMS ${ }^{1}$ \\ ${ }^{1}$ AgResearch, Grasslands Research Centre, Private Bag 11008, Palmerston North, New Zealand \\ ${ }^{2}$ Institute of Grassland and Environmental Research, North Wyke, Okehampton, UK
}

(Revised MS received 2 November 1999)

\begin{abstract}
SUMMAR Y
An investigation was made during 1988 to test the hypothesis that 'Grasslands Huia' white clover (Trifolium repens L.) could be eliminated under close sheep grazing. The effects of grazing management, topography and fertilizer on the contribution of Huia plants to the white clover population in an 85 ha experimental upland pasture ecosystem in the southern North Island, New Zealand (lat. $40^{\circ} 20^{\prime} \mathrm{S}$, long. $175^{\circ} 50^{\prime} \mathrm{E}, 125-350 \mathrm{~m}$ altitude) were quantified 11 years after oversowing. Replicated sampling sites (108 in total) were located on nine combinations of slope and aspect within grazing management treatments comprising rotational grazing with cattle (RC), rotational grazing with sheep (RS) and continuous grazing with sheep (CS), with high and low fertilizer treatments in each case. White clover occurrence, leaf area, phosphoglucoisomerase-2 (PGI-2) allele frequencies and the proportion of Grasslands Huia plants in the white clover population were determined at each site. White clover frequency was lower on steeper slopes. Aspect, slope and grazing management affected area of individual clover leaves. The proportion of Huia plants in the white clover population averaged $54 \cdot 9,49.0$ and $33.6 \%$ for RC, RS and CS, respectively $(P<0.039$, 5 D.F.). Fertilizer and topography did not affect the proportion of Huia. It was concluded that although Huia did persist after 11 years of close sheep grazing, its contribution to the total white clover population was unsatisfactory in some cases, and use of better adapted cultivars is suggested.
\end{abstract}

\section{INTRODUCTION}

White clover (Trifolium repens $\mathrm{L}$.) is the main pasture legume in many temperate grasslands, and contributes nitrogen through fixation, improves the nutritive value of the herbage, and complements the growth pattern of the main grass species (Frame 1993; Sprent \& t'Mannetje 1996). In low fertility New Zealand upland pastures the content of white clover and other legumes is commonly less than $15 \%$ of the biomass (Lambert et al. 1986a) and thus is a limitation to production (Lambert et al. 1983). Procedures for increasing the legume content include manipulating

* To whom all correspondence should be addressed. Email: barkerd@agresearch.cri.nz the genotypic composition of white clover by oversowing more productive cultivars, alleviation of deficiencies in soil nutrition and introduction of more intensive grazing management (Lambert et al. 1986 b).

The genotypic composition of a species within pasture is highly responsive to management and topography. This change usually results from natural selection, i.e. survival of genotypes best adapted to their immediate environment and loss of those that are not (Brock \& Caradus 1995). Harris \& Brougham (1970) found lax grazing resulted in dominance of a ryegrass population by genotypes more similar to annual ryegrass (Lolium multiflorum Lam.) and that continuous grazing resulted in dominance by genotypes more similar to perennial ryegrass (L. perenne L.). Clements \& Easton (1974) found that five years of continuous sheep grazing reduced mean leaf size and 
changed the esterase isozyme frequencies of a Holcus lanatus L. var Massey Basyn population, compared with the original seed line sown. Little is known about management effects on the genotypic composition of white clover populations.

Where the genotypic composition of a species within pasture is modified by introduction of new germplasm, there is usually partial replacement of the original population by the sown cultivar, and loss of new cultivar genotypes not adapted to the environment into which they were placed. In New Zealand upland pasture the persistence of an oversown line of Lotus pedunculatus Cav. ('Grasslands Maku') was investigated in relation to management and topography, and its contribution to the Lotus pedunculatus population was found to vary with slope and aspect (Hopkins et al. 1993). Sanders et al. (1989) found the contribution of L. perenne L. var Grasslands Nui in the L. perenne population of dry New Zealand upland pasture averaged $26 \%$ five years after oversowing. Similarly for white clover, using cyanogenesis as a marker, it was calculated in upland pasture that at 5 years after oversowing Huia contributed $67 \%$ to white clover production under rotational grazing with cattle, $39 \%$ under rotational grazing with sheep, and $31 \%$ under continuous grazing with sheep (Lambert et al. 1986b). Chapman et al. (1993a,b), also using cyanogenesis, determined that Huia and 'Grasslands Tahora' cultivars contributed 43 and $58 \%$, respectively, to the white clover population 4 years after oversowing in upland pasture under sheep grazing. At 8 years after oversowing, the respective contributions of Huia and Tahora were 13.7 and $56.1 \%$ (Chapman 1997). Using 'feather-mark' Grasslands Huia white clover it was found that less than $10 \%$ of transplants survived 3 years under predominantly sheep grazing, but $38 \%$ survived under predominantly cattle grazing (Charlton 1984). Although these short-term studies concluded that Huia had poor persistence in upland pasture, no studies have been conducted to determine whether or not Huia is eliminated in the long term.

One method for determining the proportion of a cultivar sown into an existing sward uses the relative frequencies of isozyme bands (electromorphs) of the enzyme phosphoglucoisomerase-2 (PGI-2) (Gilliland et al. 1982; Kennedy et al. 1985; Prins et al. 1989; Sanders et al. 1989, Adam et al. 1993; Wedderburn et al. 1996). The PGI system in white clover was investigated by Michaelson-Yeates (1986) and in a set of 45 families five alleles (A, B, C, D and F) were found at the PGI-2 locus. As white clover is a tetraploid $(2 n=4 x=32)$, any gene locus can be represented by four different alleles. For the enzyme PGI-2, the maximum number of alleles in any individual plant was three, with $\mathrm{CC}$ homozygous in virtually all plants. Michaelson-Yeates (1986) showed that white clover behaved as an amphidiploid and this, together with the fixed $\mathrm{CC}$ allele, enabled the statistical methodology of a diploid (Kennedy et al. 1985) to be modified for white clover. Where cultivars with different allele frequencies are sown in mixture, the resultant population will have an allele frequency which is a combination of the allele frequencies of the individual cultivars, weighted in proportion to the respective contribution of each cultivar to the population. Using this approach, Prins et al. (1989) found 'Grasslands Kopu' contributed $43 \%$ to the white clover population of sheep-grazed lowland pasture 10 years after establishment. Adam et al. (1993) found the contribution of Huia to an upland white clover population varied between 24 and $100 \%$ at 18 months after oversowing. Wedderburn et al. (1996) found the contribution of the cultivar 'Prop' to an upland white clover population varied between 16 and $58 \%$ at 27 months after oversowing.

The objectives of this paper are firstly, to report the PGI-2 allele frequencies from electrophoretic analysis of pure lines of 'Grasslands Huia' white clover and the resident clover, and of mixed populations of these lines; secondly, to determine the relative contribution of Huia plants to the white clover population under management (fertilizer, cattle/sheep grazing) and topography (slope and aspect) treatments, 11 years after the most recent oversowing, and thirdly, to test the hypothesis that Huia could be eliminated under close sheep grazing.

\section{MATERIALS AND METHODS \\ Grazing trial}

A trial was initiated in 1974 at the Ballantrae Hill Country Research Station (lat. $40^{\circ} 20^{\prime} \mathrm{S}$, long. $175^{\circ}$ $50^{\prime} \mathrm{E}, 125-350 \mathrm{~m}$ altitude) in the southern North Island of New Zealand, to investigate the influence of fertilizer application and grazing management on an upland pasture ecosystem (Lambert et al. 1983). The experimental area was 85 ha, and included 12 farmlets of 5-15 ha each. Average annual rainfall was $1280 \mathrm{~mm}$ and mean air temperature $12 \cdot 2^{\circ} \mathrm{C}$. Soils had a fine sand and silt texture, were derived from Tertiary sediments with a small amount of loess on flatter areas, and had an initial extractable (Olsen) $\mathrm{P}$ concentration of $6 \mathrm{mg} \mathrm{P}$ per $\mathrm{kg}$ dry soil. Pasture botanical composition changed through the trial period but the most dominant grasses were Agrostis capillaris L., Anthoxanthum odoratum L. and $L$. perenne L., and the most dominant legume was white clover. Farmlet treatments comprised an incomplete factorial arrangement of four levels of superphosphate (0-9-0-11) fertilizer, four levels of grazing management, and unequal replication (Table 1). Further details are given in Lambert et al. (1983).

A mixture of seed of four legume species (white clover cv. Grasslands Huia, T. pratense L., Lotus pedunculatus Cav. and T. subteranneum L.) was over- 
Table 1. Treatment structure for 12 farmlets, comprising an incomplete factorial arrangement of four levels of superphosphate (0-9-0-11) fertilizer and four levels of grazing management

\begin{tabular}{|c|c|c|c|c|c|c|}
\hline \multirow[b]{2}{*}{ Treatment } & \multicolumn{2}{|c|}{ Fertilizer application (kg $\mathrm{P} /$ ha/year) } & \multicolumn{3}{|c|}{ Grazing management } & \multirow{2}{*}{$\begin{array}{c}\text { Stocking rate } \\
\text { during } 1988 \\
\text { (ewes/ha) }\end{array}$} \\
\hline & 1973-1981 & $1982-1988$ & Type & Animal & Replicates & \\
\hline H-RS & $46^{*}$ & 46 & Rotational & Sheep & 1 & $16 \cdot 1$ \\
\hline $\mathrm{H}-\mathrm{RC}$ & $46^{*}$ & 46 & Rotational & Cattle† & 1 & $16 \cdot 1$ \\
\hline $\mathrm{H}-\mathrm{CS}$ & $46^{*}$ & 46 & Continuous & Sheep & 3 & $16 \cdot 1$ \\
\hline $\mathrm{HN}-\mathrm{CS}$ & $46^{*}$ & 0 & Continuous & Sheep & 1 & $16 \cdot 1$ \\
\hline L-RS & 13 & 13 & Rotational & Sheep & 1 & $10 \cdot 3$ \\
\hline L-RC & 13 & 13 & Rotational & Cattle $\dagger$ & 1 & $10 \cdot 3$ \\
\hline L-CS & 13 & 13 & Continuous & Sheep & 3 & $10 \cdot 3$ \\
\hline $\mathrm{LN}-\mathrm{CS}$ & 13 & 0 & Continuous & Sheep & 1 & $10 \cdot 3$ \\
\hline
\end{tabular}

* Also ground lime in 1975 and 1979.

$\dagger$ Cattle grazing 1975-1981; sheep grazing 1982-1986; sheep, goat and cattle grazing 1987-1988.

sown by air, without any prior sward treatment, in June 1974 and again in October 1977 (Lambert et al. $1986 \mathrm{~b}$ ). The white clover sowing rate was $2 \cdot 5 \mathrm{~kg} / \mathrm{ha}$.

\section{Field sampling}

Sampling sites were located on nine combinations of three slopes and three aspects within the 12 farmlets $(9 \times 12=108$ sites $)$. Slope classes were micro-topographical zones of $1-12^{\circ}, 13-25^{\circ}$ and $>25^{\circ}$, equating to tracks/camps, slopes and banks, respectively (Rumball \& Esler 1968). Aspect classes were NW, SW and $\mathrm{E}$ facing slopes. During late-spring/early-summer 1988 the presence or absence of white clover was recorded within 50 equal subdivisions of a $0.5 \mathrm{~m}^{2}$ quadrat at 12 places within an approximately $15 \mathrm{~m}^{2}$ area at each of the 108 sites. Twelve white clover plants were collected from each sampling site (12 farmlets $\times 3$ slopes $\times 3$ aspects $\times 12$ plants $=1296$ plants in total) for isozyme analysis and the area of the youngest fully mature leaf of each plant measured using the method of Williams et al. (1964). Individual plants were identified at the first occurrence of white clover within the quadrat (above), were separated by 1-3 $\mathrm{m}$, and comprised at least one stolon tip, one rooted node and 5-10 leaves.

In addition to plants from the field, the allele frequency of PGI-2 allozymes was determined for approximately 100 glasshouse-grown seedlings for both 'Grasslands Huia' and the resident white clover population 'Ballantrae'. The Huia that was characterized was not identical to the actual seed line sown, but was an equal mix of four lines harvested in 1973 and 1977 (Grasslands accession numbers C2897, C2900, C3892, C3893). The 'Ballantrae' that was characterized was a mixture of four lines harvested from four locations within the trial area in 1973, prior to any oversowing (Grasslands accession numbers C2742, C2743, C2744, C2745).

\section{Gel electrophoresis}

The method of electrophoresis followed that of Shields et al. (1983). Leaf supernatant from individual plants was prepared on the same day as the field sampling. Leaf tissue $(c .0 \cdot 1 \mathrm{~g}$ from each of 1296 white clover plants) was ground with sand in $0.5 \mathrm{ml}$ of extraction buffer $(0 \cdot 1 \mathrm{M}$ Tris $/ \mathrm{HCl}$, pH $8 \cdot 0,0 \cdot 1 \%$ ascorbic acid, $0.114 \mathrm{~m} \alpha$-mercaptoethanol, and $10 \%$ sucrose) and then centrifuged ( $10000 \mathrm{~g}$ for $5 \mathrm{~min}$ ) to remove debris, and the supernatant frozen until required. For analysis, supernatant was thawed and $15 \mu$ l loaded into wells in $0.75 \mathrm{~mm}$ thickness polyacrylamide gels. The gels were prepared using a tris/glycine buffer system and the electrophoresis run in Biorad Box Kits

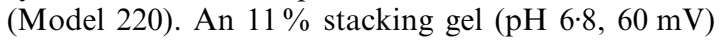
and a $5 \%$ running gel $(\mathrm{pH} 8.8,200 \mathrm{mV})$ were used. Gel buffer solutions and phosphoglucoisomerase (PGI) staining protocol were according to Hayward \& McAdam (1977).

In addition to the five alleles (A-E) reported by Prins et al. (1989), a K allele was found slightly anodal to $\mathrm{C}$ at a high frequency in the resident and mixed populations (Williams et al. 1998). Two other alleles were found at a low frequency $(<0 \cdot 1 \%)$, namely, $\mathrm{W}$ slightly cathodal to $\mathrm{C}$, and $\mathrm{M}$ closely anodal to $\mathrm{C}$, and these were totalled with $\mathrm{K}$ for statistical analysis. In standard gels $\mathrm{K}, \mathrm{W}$ and $\mathrm{M}$ merged and produced an identifiable wider band at the $\mathrm{C}$ position; however, analysis of these alleles using gradient gels (Williams et al. 1998) has shown that they segregate normally. An experienced operator could readily identify the unusually wide $\mathrm{C}$ band indicative of the presence of $\mathrm{K}$ or $\mathrm{M}$ in standard gels. Eight plants not conforming to the 'fixed-C allele' 
Table 2. Hardy-Weinberg expectations for the 16 phosphoglucoisomerase (PGI-2) phenotypes occurring in pure populations of 'Grasslands Huia' and 'Ballantrae' resident white clover, and 11 populations $(i=1-11)$ mixed in the proportions of $p_{i}$ Huia and (1- $\left.p_{i}\right)$ Resident; $\mathrm{a}_{\mathrm{h}}, \mathrm{b}_{\mathrm{h}}, \mathrm{c}_{\mathrm{h}}, \mathrm{d}_{\mathrm{h}}, \mathrm{e}_{\mathrm{h}}, \mathrm{k}_{\mathrm{h}}$, and $\mathrm{a}_{\mathrm{r}}, \mathrm{b}_{\mathrm{r}}, \mathrm{c}_{\mathrm{r}}, \mathrm{d}_{\mathrm{r}}, \mathrm{e}_{\mathrm{r}}, \mathrm{k}_{\mathrm{r}}$, are the frequencies of alleles $A, B, C, D, E$ and $K$ for Huia and 'Ballantrae' resident, respectively

\begin{tabular}{|c|c|c|c|}
\hline Phenotype* & $\begin{array}{l}\text { Expectations } \\
\text { for Huia } \dagger\end{array}$ & $\begin{array}{l}\text { Expectations } \\
\text { for Resident } \uparrow\end{array}$ & $\begin{array}{l}\text { Expectations for a mixture } \\
\text { of Huia and Resident }\end{array}$ \\
\hline $\begin{array}{l}\text { AACC/ACCC } \\
\text { ABCC } \\
\text { ADCC } \\
\text { AECC } \\
\text { AKCC } \\
\text { BBCC/BCCC } \\
\text { BDCC } \\
\text { BECC } \\
\text { BKCC } \\
\text { CCCC } \\
\text { DDCC/DCCC } \\
\text { DECC } \\
\text { DKCC } \\
\text { EECC/ECCC } \\
\text { EKCC } \\
\text { KKCC/KCCC }\end{array}$ & $\begin{array}{l}a_{h}^{2}+2 a_{h} c_{h} \\
2 a_{h} b_{h} \\
2 a_{h} d_{h} \\
2 a_{h} e_{h} \\
2 a_{h} k_{h} \\
b_{h}^{2}+2 b_{h} c_{h} \\
2 b_{h} d_{h} \\
2 b_{h} e_{h} \\
2 b_{h} k_{h} \\
\quad c_{h}^{2} \\
d_{h}^{2}+2 c_{h} d_{h} \\
2 d_{h} e_{h} \\
2 d_{h} k_{h} \\
e_{h}^{2}+2 c_{h} e_{h} \\
2 e_{h} k_{h} \\
k_{h}^{2}+2 c_{h} k_{h}\end{array}$ & $\begin{array}{l}a_{r}^{2}+2 a_{r} c_{r} \\
2 a_{r} b_{r} \\
2 a_{r} d_{r} \\
2 a_{r} e_{r} \\
2 a_{r} k_{r} \\
b_{r}^{2}+2 b_{r} c_{r} \\
2 b_{r} d_{r} \\
2 b_{r} e_{r} \\
2 b_{r} k_{r} \\
\quad c_{r}^{2} \\
d_{r}^{2}+2 c_{r} d_{r} \\
2 d_{r} e_{r} \\
2 d_{r} k_{r} \\
e_{r}^{2}+2 c_{r} e_{r} \\
2 e_{r} k_{r} \\
k_{r}^{2}+2 c_{r} k_{r}\end{array}$ & $\begin{array}{c}p_{i}\left(a_{h}^{2}+2 a_{h} c_{h}\right)+\left(1-p_{i}\right)\left(a_{r}^{2}+2 a_{r} c_{r}\right) \\
p_{i}\left(2 a_{h} b_{h}\right)+\left(1-p_{i}\right)\left(2 a_{r} b_{r}\right) \\
p_{i}\left(2 a_{h} d_{h}\right)+\left(1-p_{i}\right)\left(2 a_{r} d_{r}\right) \\
p_{i}\left(2 a_{h} e_{h}\right)+\left(1-p_{i}\right)\left(2 a_{r} e_{r}\right) \\
p_{i}\left(2 a_{h} k_{h}\right)+\left(1-p_{i}\right)\left(2 a_{r} k_{r}\right) \\
p_{i}\left(b_{h}^{2}+2 a_{h} c_{h}\right)+\left(1-p_{i}\right)\left(b_{r}^{2}+2 a_{r} c_{r}\right) \\
p_{i}\left(2 b_{h} d_{h}\right)+\left(1-p_{i}\right)\left(2 b_{r} d_{r}\right) \\
p_{i}\left(2 b_{h} e_{h}\right)+\left(1-p_{i}\right)\left(2 b_{r} e_{r}\right) \\
p_{i}\left(2 b_{h} k_{h}\right)+\left(1-p_{i}\right)\left(2 b_{r} k_{r}\right) \\
p_{i}\left(c_{h}^{2}\right)+\left(1-p_{i}\right)\left(c_{r}^{2}\right) \\
p_{i}\left(d_{h}^{2}+2 c_{h} d_{h}\right)+\left(1-p_{i}\right)\left(d_{r}^{2}+2 c_{r} d_{r}\right) \\
p_{i}\left(2 d_{h} e_{h}\right)+\left(1-p_{i}\right)\left(2 d_{r} e_{r}\right) \\
p_{i}\left(2 d_{h} k_{h}\right)+\left(1-p_{i}\right)\left(2 d_{r} k_{r}\right) \\
p_{i}\left(e_{h}^{2}+2 c_{h} e_{h}\right)+\left(1-p_{i}\right)\left(e_{r}^{2}+2 c_{r} e_{r}\right) \\
p_{i}\left(2 e_{h} k_{h}\right)+\left(1-p_{i}\right)\left(2 e_{r} k_{r}\right) \\
p_{i}\left(k_{h}^{2}+2 c_{h} k_{h}\right)+\left(1-p_{i}\right)\left(k_{h}^{2}+2 c_{r} k_{r}\right)\end{array}$ \\
\hline
\end{tabular}

* $\mathrm{K}$ was the total of $\mathrm{k}, \mathrm{m}$ and $\mathrm{w}$ alleles, the latter two being at a frequency of $<0.4 \%$.

$\dagger$ Where $a_{h}+b_{h}+c_{h}+d_{h}+e_{h}+k_{h}=1$ and $a_{r}+b_{r}+c_{r}+d_{r}+e_{r}+k_{r}=1$.

model (Michaelson-Yeates 1986) were omitted from analysis. The genotypes AACC and ACCC, BBCC and BCCC, DDCC and DCCC, EECC and ECCC, and $\mathrm{KKCC}$ and $\mathrm{KCCC}$ had identical banding patterns (within pairs) and expectations for these were pooled. Retrospective analysis of gels and laboratory records suggested incomplete separation of bands for many plants of one farmlet might have been due to a faulty reagent. This farmlet was excluded from subsequent analysis.

\section{Statistical analysis}

For the two pure populations, Huia and 'Ballantrae', observed frequencies of the 16 possible PGI-2 phenotypes were fitted to their Hardy-Weinberg expectations (Table 2) using the non-linear procedure (PROC NLIN) of the Statistical Analysis System (SAS) (SAS Institute, North Carolina, USA), to predict the maximum likelihood mean and asymptotic standard error for the six alleles.

It was assumed that each field population was a mixture of plants (or hybrids from natural reseeding) of only Huia and resident white clover. The two pure populations and the 11 mixed (field) populations from the included farmlets were modelled together to predict the 10 unknown allele frequencies ( 5 for each population, with the $\mathrm{k}$ allele for each population calculated as $1-(a+b+c+d+e))$, the maximum likelihood mean proportion of Huia to the white clover population $(p)$ for each included farmlet and the asymptotic standard error for the 21 model parameters, from the observed PGI-2 phenotype frequencies. The model was fitted by using 208 equations to predict the 21 unknown model parameters (Table 2) from the observed phenotypes (Tables 3 and 4), using PROC NLIN of SAS.

Further PROC NLIN analyses of PGI-2 phenotypes were performed to determine the average contribution of Huia to topographies within farmlets. There were 99 analyses ( 3 slopes $\times 3$ aspects $\times 11$ farmlets), one for each sampling site (10-12 plants) and a separate estimate of $p$ was obtained for each combination of slope, aspect and farmlet.

The proportion of Huia in the white clover population $(p)$, white clover occurrence, and mean clover leaf area were analysed by analysis of variance (ANOVA) using Type I (incremental) sums of squares of SAS. There was negligible change in the interpretation when Type III (partial) sums of squares were used. A split-plot model was used, with fertilizer and management treatments (farmlets) as main plots, and slope and aspect treatments (sampling sites) as subplots. Since there were no significant differences between $\mathrm{H}$ and $\mathrm{HN}$ treatments and $\mathrm{L}$ and $\mathrm{LN}$ treatments, $\mathrm{HN}$ and $\mathrm{LN}$ were treated as replicates of $\mathrm{H}$ and L, respectively. Significance tests of proportion data ( $p$ and occurrence) and leaf area were made following $\arcsin \left(\mathrm{x}^{1 / 2}\right)$ and $\log _{10}(\mathrm{x})$ transformation, respectively, to ensure residuals from ANOVA were normally distributed. 
Table 3. Number of observed PGI-2 phenotypes, maximum likelihood mean allele proportions and asymptotic standard error (S.E.) in parentheses, for pure populations of 'Grasslands Huia' and 'Ballantrae' resident white clover

\begin{tabular}{lcc}
\hline \hline & $\begin{array}{c}\text { Grasslands } \\
\text { Phenotype* }\end{array}$ & Resident \\
\hline AACC/ACCC & 10 & 2 \\
ABCC & 12 & 0 \\
ADCC & 2 & 0 \\
AECC & 0 & 0 \\
AKCC & 0 & 4 \\
BBCC/BCCC & 35 & 10 \\
BDCC & 9 & 3 \\
BECC & 3 & 0 \\
BKCC & 0 & 2 \\
CCCC & 13 & 33 \\
DDCC/DCCC & 8 & 0 \\
DECC & 1 & 4 \\
DKCC & 1 & 0 \\
EECC/ECCC & 0 & 0 \\
EKCC & 4 & 33 \\
KKCC/KCCC & 1 & 95 \\
Uninterpretable $\dagger$ & $1($ missing C band $)$ & $2($ with 4 bands $)$ \\
Total & 100 & 95 \\
Calculated allele proportions and standard errors in \\
parentheses & & \\
a & $0 \cdot 140(0 \cdot 012)$ & $0 \cdot 035(0 \cdot 011)$ \\
b & $0 \cdot 350(0 \cdot 014)$ & $0 \cdot 084(0 \cdot 011)$ \\
c & $0 \cdot 346(0 \cdot 019)$ & $0 \cdot 592(0 \cdot 020)$ \\
d & $0 \cdot 111(0 \cdot 012)$ & $0 \cdot 044(0 \cdot 011)$ \\
e & $0 \cdot 028(0 \cdot 012)$ & 0 \\
k & $0 \cdot 026(0 \cdot 013)$ & $0 \cdot 245(0 \cdot 013)$ \\
\hline \hline
\end{tabular}

* $\mathrm{K}$ was the total of $\mathrm{k}, \mathrm{m}$, and $\mathrm{w}$ alleles, the latter two being at a proportion of $<0.004$.

$\dagger$ Omitted from analysis.

\section{RESULTS}

'Grasslands Huia' and 'Ballantrae' white clover had distinctly different PGI-2 allele frequencies, with Huia having a higher frequency of $\mathrm{B}$ alleles and a lower frequency of $\mathrm{C}$ and $\mathrm{K}$ alleles than 'Ballantrae' (Table 3). 'Ballantrae' had no E allele.

There were large differences in the PGI-2 phenotype frequencies among the 11 farmlets, with the range in calculated proportion of Huia to the population $(p)$ between $0 \cdot 26$ and 0.65 (Table 4). The maximum likelihood ratio for model lack of fit was not significant ( $\chi^{2}=141.6$ with 174 D.F., $P=0.966$ ), and showed a good fit of the model to the observations. Fitting a simpler model to determine $p$ for the grazing treatments RS, RC and CS gave proportions of 0.49 , 0.55 and 0.34 Huia in the white clover population, respectively. The maximum likelihood ratio test for grazing treatment effects $\left(\chi^{2}=11 \cdot 7\right.$ with 2 D.F., $P=0.003$ ) was significant, showing a significant effect of grazing treatments. The maximum likelihood ratio test for fertilizer effects was not significant $\left(\chi^{2}=2 \cdot 4\right.$ with 1 D.F., $P=0 \cdot 121$ ).

The statistical model adequately determined a separate estimate of $p$ for each combination of slope, aspect and farmlet ( $n=10$ to 12 plants), although the asymptotic standard error (range of s.E. 0.186-0.338, mean $=0.221)$ was greater than when larger populations were used. Analysis of variance of the modelled proportion of Huia $(p)$ for the management by topography summaries (Table 5) found a significant difference $(P=0.039)$ among management treatments (mean S.E. $=3.45,5$ D.F.) in agreement with the maximum likelihood ratio test. The fertilizer main effect and the fertilizer $\times$ management interaction were not significant $(P \geqslant 0 \cdot 20,5$ D.F. $)$. There were no significant effects of slope, aspect, or slope $\times$ aspect interaction $(P>0 \cdot 15,40$ D.F. $)$ on the contribution of Huia to the white clover population (Table 5). The only significant interaction for the contribution of Huia to the white clover population was a four-factor interaction (management $\times$ fertilizer $\times$ aspect $\times$ slope) $(P=0 \cdot 041,40$ D.F. $)$. However, when fertilizer treatments were analysed separately the respective threefactor interactions were not significant $(P>0 \cdot 1$, 24 D.F.).

On average, $79.9 \%$ of the $0 \cdot 1 \times 0 \cdot 1 \mathrm{~m}$ areas sampled in the field contained white clover. Slope was the only treatment significantly affecting white clover occurrence $(P=0 \cdot 026,48$ D.F. $)$, with high, medium and flat slopes averaging $77 \cdot 6,84 \cdot 3$ and $87 \cdot 0 \%$ of quadrat squares having white clover present $($ s.E. $=2 \cdot 4$, 48 D.F.). All other effects were not significant ( $P>0 \cdot 12,48$ D.F.). A similar range was found for RC, RS and CS: $89 \cdot 8,82 \cdot 3$ and $76 \cdot 8 \%$, respectively, although, the larger standard error for main plots $(5 \cdot 0)$ resulted in this difference being not significant $(P=0 \cdot 19,6$ D.F. $)$.

The area of individual white clover leaves varied significantly with aspect, slope, grazing and certain of the interactions between these main effects. Table 6 shows means and standard errors for factor main effects. A significant slope $\times$ fertility $\times$ management interaction effect was the result of a significant management $\times$ slope interaction at high fertility, with no corresponding interaction at low fertility (data not shown). No significant relationship between contribution of Huia to the white clover population and the area of individual white clover leaves was found $\left(R^{2}=0 \cdot 04\right)$.

\section{DISCUSSION}

White clover was not uniformly distributed in upland pastures, and factors affecting its distribution included grazing management, fertilizer application, topography and genotypic composition of the population. In contrast to the original hypothesis and the previous 
Table 4. Observed PGI-2 phenotypes and proportion of 'Grasslands Huia' plants (p) calculated using the Hardy-Weinberg expectations given in Table 2. The 208 equations were fit as a single model to the observations to predict 11 values of $\mathrm{p}_{\mathrm{i}}$ for populations with contrasting history of fertilizer application and grazing management (see Table 1 for treatments and abbreviations)

\begin{tabular}{|c|c|c|c|c|c|c|c|c|c|c|c|}
\hline \multirow[b]{2}{*}{ Phenotype* } & \multicolumn{5}{|c|}{$\mathrm{L}$} & \multirow{2}{*}{$\begin{array}{l}\mathrm{LN} \\
\mathrm{CS}\end{array}$} & \multicolumn{4}{|c|}{$\mathrm{H}$} & \multirow{2}{*}{$\begin{array}{l}\mathrm{HN} \\
\mathrm{CS}\end{array}$} \\
\hline & RS & $\mathrm{RC}$ & $\mathrm{CS}$ & $\mathrm{CS}$ & $\mathrm{CS}$ & & $\mathrm{RS}$ & $\mathrm{RC}$ & $\mathrm{CS}$ & $\mathrm{CS}$ & \\
\hline $\mathrm{AACC} / \mathrm{ACCC}$ & 5 & 4 & 4 & 5 & 3 & 3 & 6 & 4 & 4 & 6 & 6 \\
\hline $\mathrm{ABCC}$ & 3 & 2 & 3 & 3 & 3 & 1 & 2 & 2 & 2 & 0 & 3 \\
\hline ADCC & 0 & 0 & 1 & 0 & 1 & 1 & 0 & 0 & 0 & 0 & 1 \\
\hline $\mathrm{AECC}$ & 0 & 0 & 0 & 0 & 1 & 1 & 0 & 0 & 0 & 0 & 0 \\
\hline $\mathrm{AKCC}$ & 0 & 2 & 1 & 1 & 3 & 3 & 0 & 5 & 1 & 3 & 5 \\
\hline $\mathrm{BBCC} / \mathrm{BCCC}$ & 30 & 26 & 15 & 12 & 19 & 10 & 23 & 28 & 19 & 26 & 17 \\
\hline $\mathrm{BDCC}$ & 5 & 5 & 5 & 8 & 7 & 3 & 4 & 3 & 2 & 2 & 3 \\
\hline $\mathrm{BECC}$ & 0 & 6 & 1 & 0 & 0 & 2 & 0 & 3 & 2 & 2 & 3 \\
\hline $\mathrm{BKCC}$ & 3 & 1 & 1 & 6 & 6 & 6 & 2 & 1 & 2 & 1 & 3 \\
\hline $\mathrm{CCCC}$ & 11 & 18 & 36 & 22 & 20 & 35 & 22 & 19 & 27 & 32 & 26 \\
\hline $\mathrm{DDCC} / \mathrm{DCCC}$ & 2 & 4 & 9 & 7 & 2 & 7 & 8 & 5 & 2 & 8 & 10 \\
\hline DECC & 1 & 0 & 0 & 0 & 0 & 1 & 1 & 0 & 0 & 0 & 0 \\
\hline $\mathrm{DKCC}$ & 10 & 8 & 3 & 2 & 6 & 3 & 4 & 6 & 8 & 3 & 3 \\
\hline $\mathrm{EECC} / \mathrm{ECCC}$ & 2 & 3 & 4 & 2 & 2 & 6 & 7 & 2 & 4 & 4 & 4 \\
\hline $\mathrm{EKCC}$ & 1 & 1 & 1 & 1 & 2 & 0 & 0 & 7 & 3 & 0 & 1 \\
\hline $\mathrm{KKCC} / \mathrm{KCCC}$ & 33 & 28 & 19 & 38 & 28 & 26 & 25 & 21 & 31 & 21 & 20 \\
\hline Uninterpretable $\dagger$ & 2 & 0 & 5 & 1 & 5 & 0 & 4 & 2 & 1 & 0 & 3 \\
\hline Total & 108 & 108 & 108 & 108 & 108 & 108 & 108 & 108 & 108 & 108 & 108 \\
\hline$p, \%$ & $0 \cdot 508$ & $0 \cdot 536$ & $0 \cdot 398$ & $0 \cdot 315$ & $0 \cdot 376$ & $0 \cdot 267$ & $0 \cdot 489$ & $0 \cdot 649$ & $0 \cdot 340$ & $0 \cdot 465$ & $0 \cdot 440$ \\
\hline S.E. & 0.068 & 0.068 & 0.070 & 0.071 & 0.069 & 0.071 & 0.069 & 0.068 & $0 \cdot 070$ & 0.068 & 0.067 \\
\hline
\end{tabular}

* $\mathrm{K}$ was the total of $\mathrm{k}, \mathrm{m}$, and $\mathrm{w}$ alleles, the latter two being at a proportion of $<0 \cdot 004$.

$\uparrow$ Omitted from analysis (indistinct bands or evidence of variation in fixed-CC)

suggestions from shorter-term studies that Huia might be eliminated under grazing in upland pastures (Charlton 1984; Chapman 1997), this study found that Huia remained persistent at an average $39 \%$ of the white clover population after 11 years of close sheep grazing. Better persistence of Huia under rotational grazing with cattle was consistent with previous studies (Charlton 1984; Lambert et al. $1986 b)$. Huia is a medium-leaved variety, whereas the resident clover was a small-leaved type, morphologically similar to Kent wild white (Lambert et al. $1986 b$ ). Differences in the performance of varieties of white clover of different leaf size, when compared under rotational grazing $v$. continuous grazing, or under cutting $v$. continuous sheep grazing, have generally shown advantages to small-leaved types under continuous grazing (Evans \& Williams 1987; Brock 1988; Swift et al. 1992; Brock \& Caradus 1995). Differences in varietal response are attributed more to the frequency of defoliation, than other effects of grazing behaviour such as treading or excreta return (Curll \& Wilkins 1983). White clover responds to repeated defoliation of the type encountered under continuous sheep grazing, with reductions in leaf area and stolon production (Briseño de la Hoz \& Wilman 1981). The relatively greater carbon allocation to stolons for small-leaved types allows them to maintain a higher stolon density in the sward (Wilman \& Asiegbu 1982). In the present study the proportionately greater contribution of the resident white clover, 'Ballantrae', in the clover gene pool on the CS farmlets, and corresponding greater proportion of Huia in the RC farmlets, is consistent with this explanation. Clark et al. (1984) examined defoliation intervals within the trial utilized for this study and these were generally less for CS than RS.

The lack of any phosphorus fertilizer effect on the contribution of Huia to the white clover population is consistent with the result of Chapman et al. (1993a) who found no effect of phosphate fertilizer on the contribution of Huia to white clover populations in upland pastures. Such a result suggests a similar response to phosphate for the two clover populations. Both Hart (1986) and Caradus et al. (1992) have reported that Huia and selections from hill country material have relatively similar $\mathrm{P}$ responses.

Electrophoretic identification of phosphoglucoisomerase-2 (PGI-2) allele frequencies was a useful technique for determining the proportion of Grasslands Huia to the white clover population of longterm field pastures. This method integrated contributions from cross pollination and natural reseeding, 
Table 5. Proportion of 'Grasslands Huia' ( $p$ ) in 99 white clover populations calculated using the Hardy-Weinberg expectations given in Table 2. Each population comprised 10-12 plants from a factorial combination of slope $\left(0-12^{\circ}, 13-25^{\circ},>26^{\circ}\right)$ and aspect (east, south-west, north-west) within 11 farmlets (see Table 1 for treatments and abbreviations)

\begin{tabular}{|c|c|c|c|c|c|c|c|c|c|c|c|c|c|}
\hline \multirow[b]{2}{*}{ Slope } & \multirow[b]{2}{*}{ Aspect } & \multicolumn{5}{|c|}{$\mathrm{L}$} & \multirow{2}{*}{$\begin{array}{l}\text { LN } \\
\text { CS }\end{array}$} & \multicolumn{4}{|c|}{$\mathrm{H}$} & \multirow{2}{*}{$\begin{array}{l}\mathrm{HN} \\
\mathrm{CS}\end{array}$} & \multirow[b]{2}{*}{ Mean } \\
\hline & & $\mathrm{RS}$ & $\mathrm{RC}$ & $\mathrm{CS}$ & $\mathrm{CS}$ & $\mathrm{CS}$ & & $\mathrm{RS}$ & $\mathrm{RC}$ & $\mathrm{CS}$ & $\mathrm{CS}$ & & \\
\hline $0-12^{\circ}$ & E & $0 \cdot 807$ & $0 \cdot 486$ & 0.775 & $0 \cdot 493$ & 0.332 & $0 \cdot 048$ & $0 \cdot 208$ & $0 \cdot 506$ & $0 \cdot 182$ & $0 \cdot 236$ & $0 \cdot 279$ & $0 \cdot 442$ \\
\hline $0-12^{\circ}$ & SW & $0 \cdot 572$ & 0.411 & $0 \cdot 864$ & $0 \cdot 312$ & 0.541 & 0.637 & $0 \cdot 0$ & 0.766 & $0 \cdot 316$ & $0 \cdot 460$ & 0.415 & 0.456 \\
\hline $0-12^{\circ}$ & NW & 0.525 & 0.476 & $0 \cdot 241$ & $0 \cdot 131$ & $0 \cdot 241$ & 0.036 & 0.604 & 0.661 & 0.468 & $1 \cdot 061$ & 0.446 & 0.511 \\
\hline $13-25^{\circ}$ & E & $0 \cdot 109$ & 0.545 & 0.009 & $0 \cdot 104$ & $0 \cdot 236$ & $0 \cdot 266$ & $0 \cdot 239$ & $0 \cdot 188$ & $0 \cdot 446$ & 0.598 & 0.657 & $0 \cdot 300$ \\
\hline $13-25^{\circ}$ & SW & 0.356 & 0.202 & $0 \cdot 162$ & $0 \cdot 389$ & 0.440 & 0.0 & 0.768 & 0.378 & 0.091 & $0 \cdot 108$ & 0.528 & $0 \cdot 366$ \\
\hline $13-25^{\circ}$ & NW & $0 \cdot 219$ & 0.389 & $0 \cdot 193$ & $0 \cdot 301$ & 0.031 & $0 \cdot 343$ & $0 \cdot 430$ & $1 \cdot 090$ & $0 \cdot 324$ & $0 \cdot 250$ & $0 \cdot 178$ & $0 \cdot 418$ \\
\hline$>26^{\circ}$ & E & $0 \cdot 320$ & 0.351 & 0.518 & $0 \cdot 272$ & 0.577 & $0 \cdot 425$ & 0.539 & 0.619 & $0 \cdot 0$ & $0 \cdot 0$ & 0.783 & 0.423 \\
\hline$>26^{\circ}$ & SW & 0.095 & 0.744 & 0.334 & $0 \cdot 273$ & $0 \cdot 403$ & $0 \cdot 318$ & $0 \cdot 348$ & $0 \cdot 250$ & $0 \cdot 281$ & 0.528 & $0 \cdot 198$ & $0 \cdot 351$ \\
\hline$>26^{\circ}$ & NW & $0 \cdot 481$ & 0.566 & 0.069 & 0.067 & 0.286 & $0 \cdot 154$ & $9 \cdot 525$ & 0.624 & 0.601 & 0.329 & $0 \cdot 303$ & 0.459 \\
\hline Mean & & $0 \cdot 387$ & $0 \cdot 463$ & 0.352 & $0 \cdot 260$ & $0 \cdot 343$ & $0 \cdot 247$ & $0 \cdot 407$ & 0.565 & $0 \cdot 301$ & $0 \cdot 397$ & 0.421 & $0 \cdot 375$ \\
\hline
\end{tabular}

Table 6. Mean area per white clover leaf $\left(\mathrm{cm}^{2} /\right.$ leaf $)$ for three grazing management treatments, three slope classes, three aspects and two fertilities (abbreviations as for Table 1 ); $\log _{10}$-transformed data and S.E. in parentheses

\begin{tabular}{lcccc}
\hline \hline Effect & & & & S.E. \\
\hline Grazing & & & & \\
management & $\mathrm{RC}$ & $\mathrm{RS}$ & $\mathrm{CS}$ & \\
& $1 \cdot 82$ & $1 \cdot 41$ & $1 \cdot 01$ & \\
& $(0 \cdot 56)$ & $(0 \cdot 23)$ & $(-0 \cdot 036)$ & $(0 \cdot 139,6$ D.F. $)$ \\
Slope & $0-12^{\circ}$ & $13-25^{\circ}$ & $>26^{\circ}$ & \\
& $1 \cdot 53$ & $1 \cdot 48$ & $1 \cdot 24$ & \\
& $(0 \cdot 30)$ & $(0 \cdot 29)$ & $(0 \cdot 17)$ & $(0 \cdot 041,48$ D.F. $)$ \\
Aspect & $\mathrm{E}$ & $\mathrm{NW}$ & $\mathrm{SW}$ & \\
& $1 \cdot 32$ & 1.36 & $1 \cdot 56$ & \\
& $(0 \cdot 17)$ & $(0 \cdot 22)$ & $(0 \cdot 37)$ & $(0 \cdot 041,48$ D.F. $)$ \\
Fertility & $\mathrm{H}$ & $\mathrm{L}$ & & \\
& 1.54 & 1.29 & & \\
& $(0.33)$ & $(0 \cdot 18)$ & & $(0 \cdot 12,6$ D.F. $)$ \\
\hline \hline
\end{tabular}

vegetative spread of Huia stolons, and survival of original plants. This study assumed that the mixture of four Huia lines characterized for PGI-2 had a similar frequency to the Huia oversown. This assumption was justified by the facts that Huia is a cultivar with identifiable parentage; that the Huia seed characterized for PGI-2 frequency was of similar age to the seed oversown; and that the PGI-2 frequency was similar to another population harvested in 1985 (W. Williams unpublished). It was further assumed that the PGI-2 frequency of the resident population was identical across the range of treatments sampled. This assumption was consistent with previous PGI-isozyme studies (Prins et al. 1989; Sanders et al. 1989), and the 'Ballantrae' seed used was a mixture from four sites within the trial area.

Since this isozyme method was based on individual plants, differences in productivity per plant would bias determination of the contribution to biomass. The average $54.9,49 \cdot 0$ and $34.3 \%$ contribution of Huia to the white clover population for RC, RS and $\mathrm{CS}$, respectively, for this study was consistent with the 67,39 and $31 \%$ contribution of Huia to the white clover production determined using cyanogenesis by Lambert et al. $(1986 b)$ within the same trial 6 years previously. The lower contribution of plants to the clover population found in this study for RC (54.9\%) than for production in the study of Lambert et al. $(1986 b)(67 \%)$ is consistent with the greater relative productivity per plant of Huia determined by Lambert et al. (1986b). The average proportion of Huia (43\%) 4 years after oversowing found by Chapman et al. $(1993 a, b)$ under sheep grazing in hill country, was also consistent with the $49 \%$ found for $\mathrm{RS}$ in this study. In contrast, however, was the low proportion of Huia $(14 \%) 8$ years after oversowing in the same study (Chapman 1997). It was possible that the putand-take grazing system in their study may have resulted in a more severe grazing pressure and lower persistence of Huia than this study.

The relatively high contribution of Huia to some white clover populations in hill country $(24 \cdot 2,92 \cdot 4$ and $100 \%$ ) found by Adam et al. (1993) suggests there may be potential benefits in herbicide control of the existing white clover population (not done for this study). However, the proximity of the Adam et al. (1993) study to establishment (two years after oversowing) suggests loss of Huia might still have been likely over subsequent years. The absence of any clear benefit in sown cultivar persistence between two 
herbicide treatments of varying severity (Wedderburn et al. 1996), and the persistence of Huia without herbicide treatment in this study, suggests the conditions for using herbicides to aid white clover establishment from oversowing require further definition.

The relatively low contribution of Huia to the white clover populations questions the suitability of Huia for use in sheep-grazed upland pasture, an issue also raised by Charlton (1984). Although the transplant method of Charlton (1984) may have underestimated the contribution of Huia resulting from oversowing, it is likely that it is difficult to dramatically change upland pasture white clover populations by oversowing Huia. The greater proportion of 'Grasslands Tahora' in sheep-grazed upland pasture $(58 \%)$
(Chapman et al. 1993b; Chapman 1997) suggested the better adaptation of this cultivar in upland pasture.

We thank Lorelle Phillips for assistance with isozyme analysis, Jillian Kerr and Brian Devantier for assistance with white clover dissections, Robert Fletcher and David Baird for assistance with statistical analysis, Ballantrae farm staff for maintenance of the trial area and Gerald Lockett, Margot Forde Germplasm Centre, AgResearch for seed and seed-harvest information. This project was funded by the (NZ) Foundation for Research, Science and Technology (FRST), Hill-land Sustainability Programme, Contract C10308, and Alan Hopkins was supported by a fellowship from the Stapledon Memorial Trust.

\section{REFERENCES}

Adam, K. D., Wedderburn, M. E. \& Greaves, L. A. (1993). Use of allozyme genetic markers to follow the establishment of white clover oversown into hill country pastures. In Proceedings of the XVII International Grassland Congress, 1993, pp. 1046-1048.

Briseño De La Hoz, V. M. \& Wilman, D. (1981). Effects of cattle grazing, sheep grazing, cutting and sward height on a grass-white clover sward. Journal of Agricultural Science, Cambridge 97, 699-706.

BRoCK, J. L. (1988). Evaluation of New Zealand bred white clover cultivars under rotational grazing and set stocking with sheep. Proceedings of the New Zealand Grassland Association 49, 203-206.

BRoCK, J. L. \& CARADUS, J. R. (1995). Influence of grazing management and drought on white clover population performance and genotypic frequency. Agronomy Society of New Zealand Special Publication No. 11, pp. 79-82.

Caradus, J. R., Mackay, A. D., Wewala, S., Dunlop, J., Hart, A., van den Bosch, J., Lambert, M. G. \& Hay, M. J. M. (1992). Inheritance of phosphorus response in white clover (Trifolium repens L.). Plant and Soil 146, 199-208.

Chapman, D. F. (1997). Phosphorus availability, defoliation tolerance, and genetic differentiation in white clover. In Proceedings of the XVIII International Grassland Congress, Canada, Section 10, pp. 59-60.

Chapman, D. F., Mackay, A. D., Devantier, B. P. \& Dyмоск, N. (1993a). Impact of white clover cultivars on nitrogen fixation and livestock production in a New Zealand hill pasture. In Proceedings of the XVII International Grassland Congress, 1993, pp. 420-421.

Chapman, D. F., Mackay, A. D., Devantier, B. P., Dymock, N. \& Anderson, C. B. (1993b). Effects of clover cultivar and fertilizer on characteristics of white clover (Trifolium repens L.) plants and populations in a hill pasture. New Zealand Journal of Agricultural Research 36, 87-98.

Charlton, J. F. L. (1984). Persistence of Grasslands Huia white clover (Trifolium repens L.) in hill country pastures. Proceedings of the New Zealand Grassland Association 45, 131-139.
Clark, D. A., Chapman, D. F., Land, C. A. \& Dymock, N. (1984). Defoliation of Lolium perenne and Agrostis spp. tillers, and Trifolium repens stolons in set-stocked and rotationally grazed hill pastures. New Zealand Journal of Agricultural Research 27, 289-301.

Clements, R. J. \& Easton, H. S. (1974). Genetic shifts in a Yorkshire Fog population grazed by sheep 1. Population changes induced by continuous hard grazing. Proceedings of the New Zealand Grassland Association 35, 268-277.

Curle, M. L. \& Wilkins, R. J. (1983). The comparative effects of defoliation, treading and excreta return on a Lolium perenne-Trifolium repens pasture grazed by sheep. Journal of Agricultural Science, Cambridge 100, 451460.

Evans, D. R. \& Williams, T. A. (1987). The effect of cutting and grazing managements on dry matter yield of white clover varieties (Trifolium repens) when grown with $\mathrm{S} 23$ perennial ryegrass. Grass and Forage Science 42, 153159.

Frame, J. (ed) (1993). White Clover in Europe-State of the Art. FAO REUR Technical Series 29, 153 pp.

Gilliland, T. J., Camlin, M. S. \& Wright, C. E. (1982). Evaluation of phosphogluco-isomerase allozyme electrophoresis for the identification and registration of cultivars of perennial ryegrass (Lolium perenne). Seed Science and Technology 10, 415-430.

Harris, W. \& Brougham, R. W. (1970). The effect of grazing on the persistence of genotypes in a ryegrass population. New Zealand Journal of Agricultural Research 13, 263-278.

HART, A. L. (1986). A comparison of the response to phosphorus of Trifolium repens 'Grasslands Huia' and 'Grasslands Tahora' in a controlled environment. New Zealand Journal of Agricultural Research 29, 179-182.

Hayward, M. D. \& MCAdam, N. J. (1977). Isozyme polymorphism as a measure of distinctiveness and stability in cultivars of Lolium perenne. Zeitschrift für Pflanzenzüchtung 79, 59-68.

Hopkins, A., Scott, A. G., Costall, D. A., Lambert, M. G. \& CAmpbell, B. D. (1993). Distribution of diploid and tetraploid Lotus pedunculatus plants in moist, North 
Island hill country. New Zealand Journal of Agricultural Research 36, 429-434.

Kennedy, S. J., Gardiner, S. J., Gilliland, T. J. \& Camlin, M. S. (1985). The use of electrophoretic techniques to distinguish perennial ryegrass cultivars sown in mixtures. Journal of Agricultural Science, Cambridge 104, 1-9.

Lambert, M. G., Clark, D. A., Grant, D. A. \& Costall, D. A. (1983). Influence of fertilizer and grazing management on North Island moist hill country. 1. Herbage accumulation. New Zealand Journal of Agricultural Research 26, 95-108.

Lambert, M. G., Clark, D. A., Grant, D. A. \& Costall, D. A. (1986a). Influence of fertilizer and grazing management on North Island moist hill country. 2. Pasture botanical composition. New Zealand Journal of Agricultural Research 29, 1-10.

Lambert, M. G., Clark, D. A., Grant, D. A. \& Costall, D. A. $(1986 b)$. Influence of fertilizer and grazing management on North Island moist hill country. 3. Performance of introduced and resident legumes. New Zealand Journal of Agricultural Research 29, 11-21.

Michaelson-Yeates, T. P. T. (1986). Phosphoglucoisomerase variation in Trifolium repens. Genetica 70, 53-58.

Prins, E., SANDers, P. M. \& Lyons, T. B. (1989). Use of electrophoretic techniques to identify the proportion of an improved white clover cultivar ('Grasslands Kopu') in a mixed sward. New Zealand Journal of Agricultural Research 32, 515-520.

Rumball, P. J. \& Esler, A. E. (1968). Pasture pattern on grazed slopes. New Zealand Journal of Agricultural Research 11, 575-588.

Sanders, P. M., Barker, D. J. \& Wewala, G. S. (1989). Phosphoglucoisomerase-2 allozymes for distinguishing perennial ryegrass cultivars in binary mixtures. Journal of Agricultural Science, Cambridge 112, 179-184.

Shields, C. R., Orton, T. J. \& Stuber, C. W. (1983). An outline of general resource needs and procedures for the electrophoretic separation of active enzymes from plant tissue. In Isozymes in Plant Genetics and Breeding, Part A (Eds S. D. Tanksley \& T. J. Orton), pp. 443-468. Amsterdam: Elsevier.

Sprent, J. \& T'Mannetje, L. (1996). The role of legumes in sustainable farming systems; past, present and future. In Legumes in Sustainable Farming Systems. Occasional Symposium no. 30, British Grassland Society (Ed. D. Younie), pp. 2-14. Harley: BGS.

Swift, G., Morrison, M. W., Cleland, A. T., SmithTAYloR, C. A. B. \& Dickson, J. M. (1992). Comparison of white clover varieties under cutting and grazing. Grass and Forage Science 47, 8-13.

Wedderburn, M. E., Adam, K. D., Greaves, L. A. \& CARTER, J. L. (1996). Effect of oversown ryegrass (Lolium perenne) and white clover (Trifolium repens) on the genetic structure of New Zealand hill pastures. New Zealand Journal of Agricultural Research 39, 41-52.

Williams, R. F., Evans, L. T. \& Ludwig, L. J. (1964). Estimation of leaf area for clover and lucerne. Australian Journal of Agricultural Research 15, 231-233.

Williams, W. M., Mason, K. M. \& Williamson, M. W. (1998). Genetic analysis of shikimate dehydrogenase allozymes in Trifolium repens L. Theoretical and Applied Genetics 96, 859-868.

Wilman, D. \& Asiegbu, J. E. (1982). The effects of variety, cutting interval and nitrogen application on the morphology and development of stolons and leaves of white clover. Grass and Forage Science 37, 15-27. 